\title{
Aikuiskasvatuksen suunnittelusta Mikkelin läänissä
}

\begin{abstract}
Pääskynen, Kari. 1982. Aikuiskasvatuksen suunnittelusta Mikkelin läänissä. Aikuiskasvatus 2, 4, 136-139. - Artikkelissa tarkastellaan läänikohtaista aikuiskasvatuksen kehittämisprojektia Mikkelin läänissä, sen periaatteita, suunnitteluotetta ja lähestymistapaa. Pyrkimyksenä on luoda laaja, kansanvaltainen osallistumisjärjestelmä. Yhteistyöhön perustuva suunnittelutoiminta nähdään tiedostamisen ohella myös oppimisena, jonka avulla voidaan luoda uusia ideoita ja tehdä hyviä päätöksiä.
\end{abstract}

Mikkelin läänin maaherran asettaman johtoryhmän ohjauksessa muotoutuu vähitellen ammatillista aikuiskoulutusta, vapaata sivistystyötä sekä avoimen korkeakoulun muotoista opetusta koskeva läänin aikuiskoulutuksen kehittämissuunnitelma.

Emme tiedä vielä, millaisia konkreettisia toimenpiteitä suunnitelma loppujen lopuksi tulee sisältämään. Tällä hetkellä voimme jo nähdä, mitä olemme oppineet valmistelun aikana.

Kajoan artikkelissani lähinnä kansalais- ja työväenopistojen sekä kansanopistojen osuuteen suunnittelussa. Voimme kysyä: mikä tässä kehittämistyössä on ollut tyypillistä ja ehkä joistakin muista hankkeista poikkeavaa?

- Suunnittelutyötä on suoritettu siten, että lähes kaikki toteuttajat ovat olleet mukana vaikuttamassa toimialansa, tässä tapauksessa toisaalta kansalais- ja työväenopistojen ja toisaalta kansanopistojen osuuteen.

- Suunnittelua on valmisteltu työseminaareissa, jotka ovat edenneet oppimisprosessina vaiheesta toiseen.

- Toisaalta suunnitelma kuvaa niitä yleisiä pyrkimyksiä ja toimia, joita on tarkoitus virittää ja toisaalta suunnitelma kertoo, mikä on kunkin toteuttajatahon panos yhteisessä kokonaisuudessa.

Tällaisen ns. osállistuvan suunnittelun ideaa on verraten seikkaperäisesti kuvannut Seymour Gold.

Jos tällaiseen kehittämisotteeseen on päädytty, niin jokin on tehnyt tämän etenemistavan mahdolliseksi. Ensimmäinen ehto on ollut se, että Mikkelin lääninhallituksen kouluosasto, jolla on keskeinen rooli työn toteuttamisessa, on innolla ja kenttään kohdistuvalla luottamuksella tehnyt kehittämistoiminnan mahdol- liseksi. Toisena ehtona on se, että toteuttajien kesken on vallinnut useampivuotista yhteistyötä, jota ovat vauhdittaneet monet erilaiset tarpeet. Tällaisia tarpeita ovat: pyrkimys vakiinnuttaa oppilaitoksen asema, halu vaikuttaa tulevaan kehitykseen, halu varautua tulevaisuuden moniin, ehkä yllättäviinkin muutoksiin. Kolmas ehto on ollut halu selkiinnyttää itseohjautuvan yhteisön filosofiasta käsin sitä osallistumisjärjestelmää, jolla toiminta turvataan sekä yhdistää osallistumisen ja ohjauksen menetelmät hedelmällisellä tavalla. Neljäntenä ehtona toiminnan suuntaamiseen on epäilemättä vaikuttanut käsityksemme kansanvallan toteuttamisesta, sen taustaideoista ja periaatteista. Viidentenä ehtona olemme selkiinnyttäneet sitä suunnitteluotetta, jolla kannattaa edetä.

\section{Lääninhallinnon rooli}

Parhaassa tapauksessa lääninhallinto kokoaa yhteen niitä organisaatioita, jotka työskentelevät samalla toimialalla. Toimialakohtainen valmistelu on erityisen tuloksellista silloin, kun läänissä on sovittu koko läänin kannalta keskeisistä kehittämistehtävistä ja suuntaviivoista. Mikkelin läänin kouluosasto ja siellä työskentelevät vapaan sivistystyön tarkastajat ovat 1970-luvun ja kuluvan vuosikymmenen ajan saattaneet oppilaitoskenttää yhteen ja perinteisen tarkastusmentaliteetin sijasta konsultoineet oppilaitoksia. Toisena vaihtoehtona lääninhallinto olisi voinut voimakkaasti ohjata oppilaitoksia lääninhallinnon asettamien mutta oppilaitoskentälle vieraiden arvojen ja periaatteiden suuntaan. Lääninhallinnon näkökulmasta kehittämissuunnittelu luo toimintaa ennustettavaksi ja säädeltäväksi. 


\section{Osallistumisjärjestelmä}

Suunnittelun tehtävänä on vähentää tulevaisuuteen liittyvää epävarmuutta. Suunnittelu lisää ennustettavuutta. Suunnittelu helpottaa säätelyä. Osallistumisjärjestelmä voi olla autoritaarisen hengen tuote. Silloin pieni suppea, "luotettava" ryhmä sopii asiat, sitten nuo asiat siunataan lähinnä kumileimasimena toimivassa neuvottelukuntatyyppisessä elimessä. Tämän kaltainen osallistumisjärjestelmä on demokraattinen pelkästään muodoltaan. Se tekee mahdolliseksi keskusjohtoisen säätelyn, jopa Fahrenheit-yhteiskunnan.

Osallistumisjärjestelmä voi olla myös aidon kansanvaltaisiin periaatteisiin nojaavan asennoitumisen tuote. Silloin koetetaan mahdollisimman laajapohjaisesti, vaiheittain toimien ja yhdessä oppien löytää mielekäs ratkaisu. Itseohjautumiskykyinen yhteisö perustuu juuri kuvattuun osallistumisjärjestelmään.

Kansanvaltaista osallistumisjärjestelmää vastaan kohdistuu runsaasti kritiikkiä, joka perustuu väärinkäsitykseen. Voidaan esimerkiksi sanoa, että kun saman alan organisaatiot pannaan yhteen suunnittelemaan, syntyy hedelmätöntä riitaa reviireistä, eduista yms. Tällaiset riidat syntyvät atomisoituneissa, toisistaan eristyneissä yksiköissä, joita hallitaan kutakin erikseen keskusohjatusti ylhäältä päin. Jos siis reviirikiistoja esiintyy kehittämistyötä lukkiuttavalla tavalla, ongelman ydin löytyy autoritaarisesta ohjausjärjestelmästä.

Vapaa sivistystyö ei ole "kilpailtu" alue. Siksipä Mikkelin läänin oppilaitoskentässä ei avoimessa keskustelussa hahmottunut mitään oleellisia ristiriitoja.

\section{Kansanvaltaisuus}

Osa päätöksistä pyritään tekemään kansalaisista huolimatta, osa heidän näkemyksensä huomioonottaen. Vaikka tie on kuljettavana silloin, kun päätökset koitetaan valmistella kansalaisten omatoimisen työskentelyn tai myötämääräämisen avulla. Suomessa lienee tilanne se, että kun valmistelu tapahtuu suppeissa elimissä, itse toimeenpano on täynnä viiveitä, muutosvastarintoja ja kitkoja. Japanin tilanteesta olen kuullut, että suunnitteluprosessi on yleensä pitkä laajapohjaisen yhteisen valmistelun vuoksi, mutta varsinainen toimeenpano sujuukin vaivattomasti, koska asiat on sisäistetty. Pyrimme mahdollisimman avoimeen ja laajapohjaiseen valmisteluun. Emme tiedä vielä, miten eri toimenpideideat lähtevät toteutumaan.

Kansalaisopistojen vuotuiset opetussuunnitelmat syntyvät melko tavalla rehtorin ja opet- tajien sekä heidän aktiivisilta kansalaisilta saamiensa vihjeiden perusteella. Toisaalta opetussuunnitelmat ovat usein myös aika tavalla kysyntälähtöisiä. Seuraava kehitysvaihe voisi olla se, että opistot kokoavat mahdollisimman edustavan joukon toimialueensa ihmisiä työseminaariin tekemään luonnosta seuraavan tai seuraavien vuosien ohjelmaksi.

\section{Suunnitteluote}

Mikäli Mikkelin läänin aikuiskasvatuksen kehittämissuunnittelussa olisi pyritty noudattamaan olemassa olevia suosituksia, pitäisi suunnitteluprosessin olla seuraava:

1. Nykytilan kuvaus

2. Kehittämistavoitteiden kuvaus

3. Tarpeet

4. Toimenpiteet

5. Aikataulu ja budjetti.

Valitsemamme suunnitteluote pohjautuu muutamiin olettamuksiin, jotka väistämättä tuottavat edelliseen verrattuna poikkeavan suunnitteluprosessin.

a. voimme kuvata sellaisen mallin, joka kuvaa opistoliikkeen peruselementtejä ja opistoliikkeen vaikuttavia ympäristötekijöitä

b. voimme luoda käsikirjoituksia (skenaarioita) siitä, millaisissa tulevaisuudentilanteissa opistot voivat toimia: millainen on opistojen toimintaympäristố esimerkiksi vuonna 2000

c. voimme hahmotella tekijöitä ja niiden välisiä suhteita jotka yhdessä osoittavat, miten luomamme tulevaisuuden tilanne saattaa syntyä

d. voimme jäsentää ne toimenpiteet, joiden avulla opistot pyrkivät toisaalta vaikuttamaan suotavien tulevaisuuden tilojen toteutumista ja toisaalta ehkäisemään kielteisinä, masentavina pidettävien tulevaisuudentilojen toteutumista

e. voimme kuvata ne menestystekijät tai vahvat puolet, joihin opiston tehtävän suorittaminen perustuu

f. voimme arvioida ne epäkohdat, jotka on hoidettava, jotta opisto saisi hyviä tuloksia

g. voimme määritellä ne toimenpiteet, joita kaikkiaan tarvitaan opiston suhteessa tulevaan toimintaympäristöön, opiston menestystekijöiden kehittämiseksi ja epäkohtien korjaamiseksi.

h. voimme sopia niistä yhteisistä toimenpiteistä ja tavoitteista, jotka vievät vapaan sivistystyön kehitystä koko läänissä eteenpäin. 
Ympäristöpsykologisesta näkökulmasta kysymyksessä on merkittävä kahden erilaisen suunnitteluotteen ero. Ensin kuvatussa mallissa on kyse territoriaalisesta, lähinnä ulkoisten ja hyvin konkreettisten asioiden hahmottelusta. Jälkimmäisessä prosessissa on kyse disteemisesta tilakokemuksesta, siis pyrkimyksestä ymmärtää käsitteellisellä tasolla ja ilmiönä sitä työtä ja arvomaailmaa, jossa eletään ja tullaan elämään.

Suunnitteluluote voi Richard Normannin mukaan olla joko tavoite-keino -lähtöinen tai prosessinäkemykseen perustuva.

Tavoite-keino -suunnittelu tähtää varmassa toimintaympäristössä jonkin selväpiirteisen asian saavuttamiseen. Prosessinäkemystä tarvitaan silloin, kun toiminnan vaikutukset eivät ole välttämättä selvästi nähtävissä, kun ympäristö on epävarma ja kun valmistelijat haluavat nähdä suunnittelun oppimisprosessina.

Mikkelin läänin aikuiskasvatuksen kehittämissuunnittelussa olemme saaneet hyviä kokemuksia suunnitteluotteesta, jossa lähdetään liikkeelle tulevaisuuden käsikirjoituksista (tosin aika alustavalla ja diffuusilla tasolla) ja jossa edetään suurelta osin prosessinäkemyksen varassa.

Suomalaisessa, usein toimikuntapohjaisessa valmistelussa lienee yleistä se, että melko nopeasti ja alkuvaiheessa pyritään konkretisoimaan mistä on kysymys, mistä periaatteista ja mistä tavoitteista pidetään kiinni.

Tällainen valmistelu on epämielekästä useasta eri syystä:

1. valmistelutapa rikkoo inhimillisen ongelmanratkaisun keskeisen lainalaisuuden (Kolbin oppimisprosessi, Kehittämistyö - kurssikirja), jonka mukaan tarkasteltavan ilmiön tiedostaminen etenee alustavasta hahmottelusta (mielikuvista) ilmiön piirteiden, rakenteen ja periaatteiden tarkasteluun, sitten ilmiön täsmälliseen rajaamiseen ja näkemysten karsimiseen sekä vihdoin käsiteltävän asian sopimiseen, toimeenpanoon

2. valmistelutapa ehkäisee oppimisprosessissa välttämättömän rekursiivisen toiminnan: on palattava välillä alkuun ja tarkistettava aikaisemmin sovittuja asioita

3. valmistelutapa vähentää demokraattisen päätöksenteon mahdollisuuksia koska useimmiten vaikutusvaltaiset tahot ja persoonallisuudet sanelevat sen, miten asioista pitää ajatella.

Olemme pyrkineet ja pyrimme jatkossakin viipymään mielikuvissa ja luonnostelmissa.
Odotamme, että voimme yhdessä löytää synteesin erilaisten näkemysten ja mielikuvien välillä. Ennen kaikkea koetamme ymmärtää, mitä tapahtuu meidän tietoisuudessamme ja mitä tapahtuu kentällä, jos joitakin ideoita luodaan ja pannaan elämään käytännössä.

\section{Kansanopistoryhmän hankkeista}

Olemme kansanopistoryhmässä alustavasti sopineet seuraavista yhteisistä toimenpiteistä:

1. Pidämme vuosittain yhteiskokouksen, jossa pohdimme ajankohtaisia ympäristössä tapahtuvia muutoksia (aiemmin selvitimme pinnallisesti sitä, mitä opistoille kuuluu), kuluneen työvuoden tuloksia ja ongelmia, alkavan työvuoden tärkeimpiä hankkeita ja uusia työmuotoja.

2. Järjestämme seminaarin, jossa kukin opisto täsmentää oman kehittämisohjelmansa.

3. Sovimme siitä, miten jäntevöitämme koulutus- ja kasvatustoiminnan kehittämistyötä tätä toimintaa kuvaavan mallin pohjalta.

4. Sovimme siitä, miten järjestämme henkilöstölle valmennusta ammattitaidon ja kehittämisvalmiuden ylläpitämiseksi.

5. Teemme yhteisen ehdotuksen aikuiskasvatuksen jatkuvan kehittämisen varmistamiseksi Mikkelin läänissä.

6. Sovimme tiedotusyhteistyöstä vuosittain.

7. Selvitämme opistokohtaisesti, millä tavoin opistot suuntaavat voimavarojaan ja toimintaansa Mikkelin läänin ja sen väestön olojen kehittämiseksi.

Kansanopistotyöryhmän väliraportti sisältää seuraavat pääkohdat:

1. Konkreetti toimenpideohjelma lähivuosiksi.

2. Ympäristöanalyysi, jonka osatekijöinä ovat yhteiskunnallinen päätöksenteko, elämäntavat, arvot, elinympäristö, demokratia, talouspolitiikka, teknologia, kulttuuri ja koulutuksellinen tasaarvo.

3. Opistokohtainen näkemys siitä, millaisia koulutustarpeita kukin opisto pyrkii toiminnassaan ottamaan huomioon ympäristöanalyysin perusteella.

4. Arviointi kansanopistojen koulutuspalvelujen saavutettavuudesta sekä tähän liittyen ennuste opistojen opiskelijamäärien kehityksestä. 
5. Opistokohtainen kuvaus opiston keskeisistä menestystekijöistä.

6. Suppea näkemys koulutuspalvelujen kehittelytyöstä.

7. Kuvaus yhteistyöstä eri aikuiskoulutustahojen sekä opistojen kesken.

8. Alustava kuvaus opistojen asemasta ja tehtävistä läänin aikuiskasvatuksen kokonaisuudessa.

9. Idealista opistojen uusista koulutustehtävistä. Nämä tehtävät on ideoitu ja johdettu useista eri lähteistä: nykyisistä koulutusohjelmista, sidosryhmien toivomuksista, opiston toimintaideasta, toivottavasta, todennäköisimmästä ja masentavasta tulevaisuudenkuvauksesta, opiston henkilöstön (lähinnä opettajien)tieto - taito -pääomasta sekä Mikkelin läänin tarpeista.

10. Opistojen suhde keskiasteen koulutukseen.

11. Opistojen suhde aikuisten ammatilliseen koulutukseen.

12. Opiskelijoiden rekrytointi.

Olemme tiedostamassa, mikä voisi olla kuvatun kehittämissuunnittelun idea. Ei ole niinkään tärkeätä, mitä ryhdytään toimeenpane- maan vaan se, miten ryhdytään tuottamaan toimenpide-ehdotuksia. Ja vielä tätäkin tärkeämpää on mielestäni oivaltaa, miksi olemme päätyneet joihinkin menettelytapoihin. Samoin olemme tiedostamassa, ettei päätarkoituksena ole saada aikaan suunnitelmaa, vaan osua oikeaan kahdella muulla suunnalla: saavuttaa yhteisiä oppimiskokemuksia ja toiseksi päästä hyvien päätösten kautta hyviin tuloksiin.

\section{Kirjallisuutta}

M. Gold, Seymour. Recreation Planning and Desing, McGraw-Hill, Inc. 1980.

Horelli, Liisa. Ympäristöpsykologia, Weilin \& Göös, Espoo 1982.

Hynynen, Pertti \& Leppo, Tapio \& Puikkonen, Juhani \& Alsta, Kaarina. Skenaariomenetelmä tulevaisuuden tutkimuksessa. Valtioneuvoston kanslian julkaisuja. Käännös ranskankielisestä julkaisusta. 1979:1. Helsinki 1979.

Torpe, Helge, Kobayashi, Shigeru. Luova johtamistapa. Suom. ruotsinkielisestä käännöksestä, Ritva Liljamo. Weilin \& Göös, Espoo 1980.

Normann, Richard. Luova yritysjohto. Weilin \& Göös, suom. Leif Sonkin. Tapiola 1976.

Pääskynen, Kari. Kehittämistyö. Suomen Nuorisoopiston johtamiskoulutuksen julkaisematon kurssikirjamoniste 1980. 